Perceptions of Palestine 



\section{Perceptions of Palestine}

Their Influence on U.S. Middle East Policy

KATHLEEN CHRISTISON

University of California Press

BERKELEY LOS ANGELES LONDON 
University of California Press

Berkeley and Los Angeles, California

University of California Press, Ltd.

London, England

(C) 1999 by the Regents of the University of California

Parts of this book first appeared in the Journal of Palestine Studies as follows: "Splitting the Difference: The Palestinian-Israeli Policy of James Baker" (autumn 1994); "U.S. Policy and the Palestinians: Bound by a Frame of Reference: (summer 1997); "Bound by a Frame of Reference, Part II: U.S. Policy and the Palestinians, 1948-88" (spring 1998); and "Bound by a Frame of Reference, Part III: U.S. Policy and the Palestinians, 1988-1998" (summer 1998). Reprinted with permission.

Library of Congress Cataloging-in-Publication Data

Christison, Kathleen, 1941-.

Perceptions of Palestine: Their Influence on U.S. Middle East Policy / Kathleen Christison.

p. $\mathrm{cm}$.

Includes bibliographical references (p.) and index.

ISBN 0-520-21717-9 (alk. paper)

1. United States-Foreign relations-Palestine. 2. PalestineForeign relations-United States. 3. United States-Foreign relations-Israel. 4. Israel-Foreign relations-United States. 5. United States - Foreign relations - 2oth century. I. Title. E183.8.P19C48 1999

$327.7305694-\mathrm{dc} 21$

$9^{8-41413}$

CIP

Manufactured in the United States of America

$\begin{array}{lllllllllllllllllll}08 & 07 & 06 & 05 & 04 & 03 & 02 & 01 & 00 & 99 & 10 & 9 & 8 & 7 & 6 & 5 & 432 & 1\end{array}$

The paper used in this publication is both acid-free and totally chlorinefree (TCF). It meets the minimum requirements of ANSI/Niso z39.481992 (R 1997) (Permanence of Paper). 
To Bill 
